\title{
State of the Art of Identification for Cyprinid Fish Larvae from Eastern North America
}

\author{
Lee A. Fuiman \\ School of Natural Resources and Great Lakes Research Division \\ S. T. Dana Building, University of Michigan, Ann Arbor, Michigan 48109 \\ John V. Conner \\ Gulf States Utilities Company \\ Post Office Box 220, St. Francisville, Louisiana 70775 \\ BARBARA F. LATHROP \\ Ichthyological Associates \\ Post Office Box 223, Etters, Pennsylvania 17319 \\ Gerard L. Buynak ${ }^{1}$ \\ Ichthyological Associates \\ Rural Delivery 1, Berwick, Pennsylvania 18603 \\ DARrel E. SNyder \\ Larval Fish Laboratory \\ Colorado State University, Fort Collins, Colorado 30523 \\ Jules J. Loos \\ Potomac Electric Power Company \\ 1900 Pennsylvania Avenue, Northwest, Washington, District of Columbia 20068
}

\begin{abstract}
Morphological characteristics are known for 62 species of cyprinid larvae in 22 genera occupying waters of North America east of the Continental Divide. Currently known diagnostic characters are presented for most of these species. Species are arranged into groups according to their relative preanal length, eye shape, preanal myomere number, and ventral pigmentation. Descriptive literature is noted, as are errors in the literature. Practical considerations for making identifications, species in need of description, and characters to be investigated are discussed.
\end{abstract}

Identification of North American cyprinid fishes at any stage in their life histories is an intimidating task. The combination of a high number of species and their great morphological similarity is a source of aggravation to many taxonomists. The problem of identification is magnified for larvae because of even greater morphological similarity, lack of knowledge of many species' larvae, lack of comparative literature, and errors in existing literature. A "stateof-the-art" paper such as this can do little to alleviate the first two problems. However, we

\footnotetext{
${ }^{1}$ Present address: 1 Game Farm Road, Frankfort, Kentucky 40601.
}

do present the current state of knowledge in a comparative framework so as to assist identifications of larvae and preparations of future descriptive and comparative studies. We identify descriptive literature and errors in that literature. Finally, we indicate taxa in need of description. Although we present current diagnoses (which may falter as the remaining species become known), it is not our intent to provide a taxonomic key. Such an undertaking would be premature given that larvae of two-thirds of the species are unknown.

\section{Scope and Organization}

Robins et al. (1980) listed 221 species and 43 genera of cyprinids from the United States and Canada. Given that taxonomic literature on lar- 
TABLE 1.-Species of eastern North American cyprinids known in their larval forms, grouped by selected character states. A species may belong to more than one group but it is listed in only the first group that describes it (read left to right, then top to bottom). $T L$ is total length.

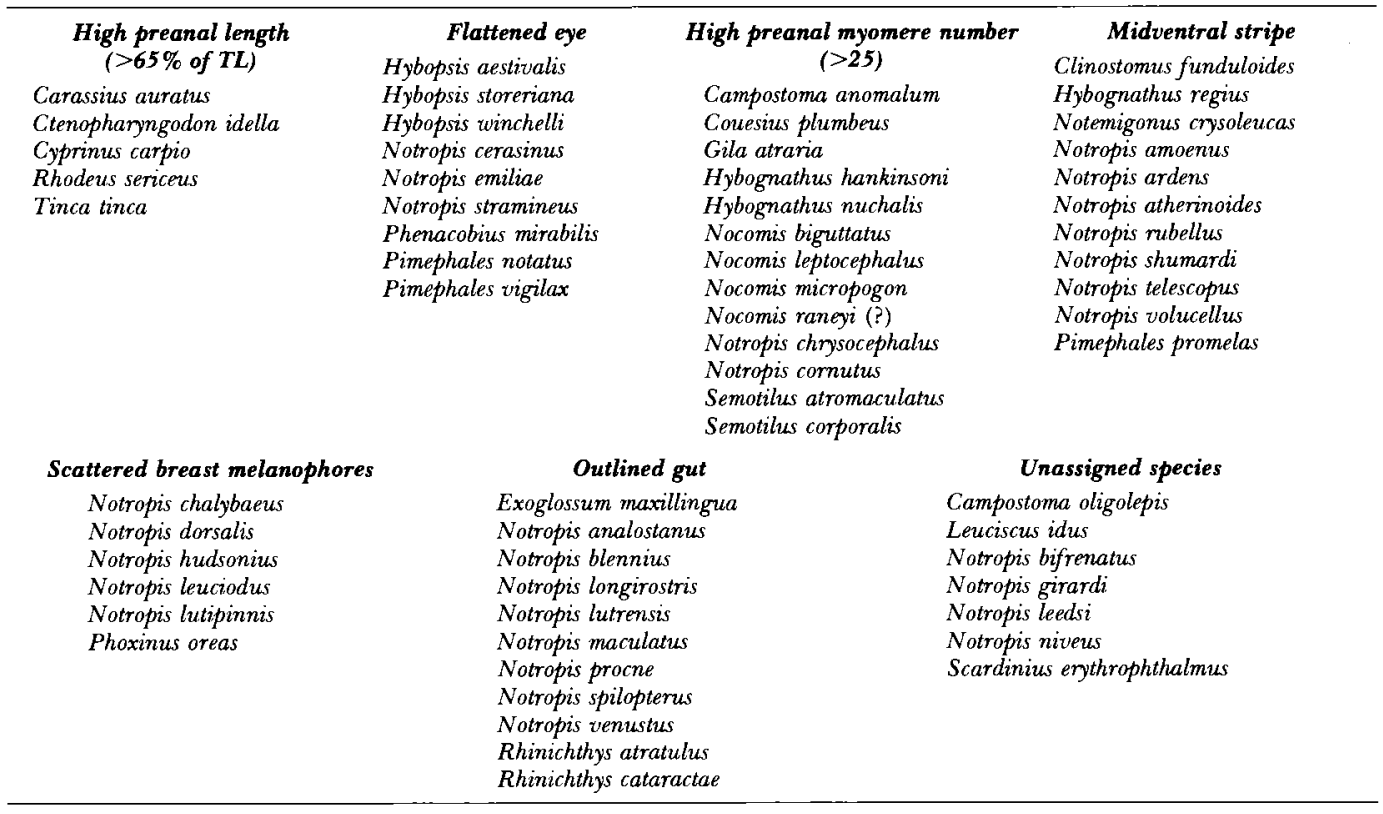

vae is nearly restricted to species of eastern North America, we limited our work to the species occurring east of the Continental Divide. Lee et al. (1980 and supplements) compiled 179 species in 25 genera in this study area, which represent $78 \%$ of the species and $58 \%$ of the genera listed by Robins et al. (1980).

In the following sections, species are discussed within groups defined by selected character states. A particular species may fit into several groups, but it is discussed only in the first one that describes it. In this way, the presentation is roughly similar to a taxonomic key. Diagnostic characters, as currently known or suspected, and references containing new (at that time) information are cited. An additional paragraph discussing published errors or information on geographic variation is included whenever possible. Most characteristics of species were taken from the literature and comparisons were based on this information combined with personal experiences of the authors. Wherever we contributed our own original descriptive data, the respective author's initials are given in parentheses. Preanal myomere numbers are presented in figures for most groups or subgroups and species are discussed in the text in approximately the same sequence in which they are presented in these figures. Preanal myomeres include all segments anterior to, and transected by, a vertical line drawn from the anus. Myomere data were taken from the literature cited in the text, but those from Fish (1932) were not included because of doubt that she was able to observe all myomeres present in a given specimen. This is based on discordance of her reports with those of more recent studies on larvae and with vertebra counts of adults. Lengths of specimens are reported as mm total length (TL).

\section{Diagnoses}

Four major characters are useful in segregating all cyprinid larvae into distinct, though unrelated, groups. These include relative preanal length, eye shape, preanal myomere number, and midventral pigmentation (Table $1)$.

\section{Relative Preanal Length (As \% of TL)}

Nearly all North American cyprinid larvae have a relative preanal length between 45 and $65 \%$ throughout development, usually 55 to $62 \%$. However, five species (all Eurasian intro- 
a)

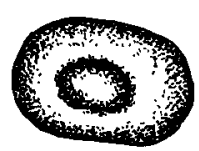

b)

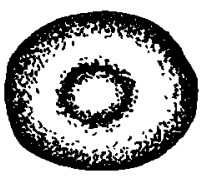

c)

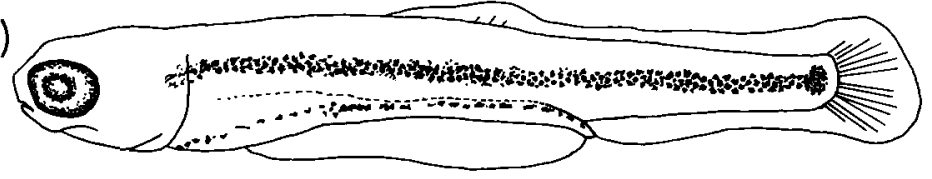

d)

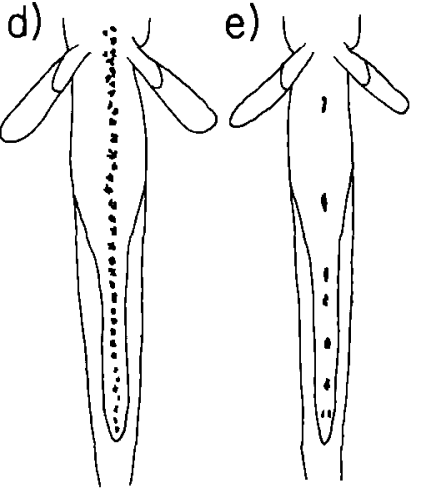

f)

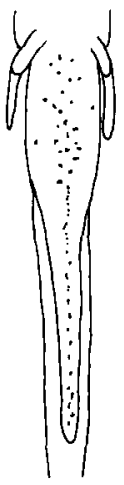

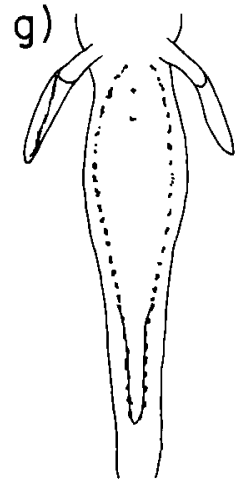

FIGURE 1.-Characters for distinguishing groups of cyprinid larvae. (a) flattened eye; (b) rounded eye; (c) high preanal myomere number associated with broad midlateral stripe, caudal spot, and ventrolateral stripe; $(d, e)$ midventral stripe as in Notemigonus crysoleucas $(d)$ and Notropis atherinoides $(e) ;(f)$ scattered breast pigment; $(g)$ outlined gut.

ductions, Table 1) exhibit a large relative preanal length (65-74\%). Usually, however, allometry causes the relative preanal length to decrease with growth. Recognition of this trend ameliorates the difficulty imposed by the overlap at $65 \%$.

Ctenopharyngodon idella is easily distinguished from the others of this group by the presence of 30 to 33 preanal myomeres. Larger larvae develop only 7 to 9 dorsal fin rays; Carassius auratus and Cyprinus carpio develop more than 15. References (in part): Nakamura (1969), Soin and Sukhanova (1972), Conner et al. (1980).

Carassius auratus and Cyprinus carpio are robust and often darkly pigmented (especially on the dorsum). Both possess a dark, internal band of pigment that tracks the dorsum of the gut and swim bladder. This band bifurcates dorsoventrally anteriad, at the pectoral buds. The dorsal branch of this "Y" pattern extends beyond the anterior edge of the auditory vesicle in Carassius auratus. Further, this species has fewer preanal myomeres ( 17 to 20 whole myomeres anterior to the anus, add 1 or 2 to conform to our conventional count). Cyprinus carpio has more preanal myomeres (21 to 24 whole myomeres) and the dorsal branch of the "Y" pattern terminates at the anterior edge of the auditory vesicle (Gerlach 1983). References (in part): Carassius auratus_Battle (1940), Ka- jishima (1960), Nakamura (1969), Taber (1969), Lippson and Moran (1974), Loos et al. (1979), Wang and Kernehan (1979); Cyprinus carpioSmallwood and Smallwood (1931), Fish (1932), Nakamura (1969), Lippson and Moran (1974), Hogue et al. (1976), Jones et al. (1978), Loos et al. (1979), Wang and Kernehan (1979), Conner et al. (1980), Snyder (1981).

Fish (1932) illustrated a 7.5-mm Cyprinus carpio but identified it as Moxostoma aureolum $(=M$. macrolepidotum) (Snyder and Douglas 1978). Fish's error was transcribed by Mansueti and Hardy (1967). Fish also described a 10.0- and a $30.75-\mathrm{mm} \mathrm{C}$. carpio with 18 and 19 preanal myomeres and a $13.3-\mathrm{mm}$ specimen with "21(22)" preanal myomeres. Combined with the unexpectedly advanced state of development illustrated in the $10.0-\mathrm{mm}$ specimen, these counts indicate that only the $13.3-\mathrm{mm}$ description and illustration are that of Cyprinus carpio. The remaining information probably relates to $\mathrm{Ca}$ rassius auratus. Fish's illustration of a $10.0-\mathrm{mm}$ "Cyprinus carpio" and associated descriptive data were reproduced by Mansueti and Hardy (1967), Lippson and Moran (1974), Jones et al. (1978), Wang and Kernehan (1979), and Heufelder and Fuiman (1982).

Tinca tinca is 4 to $5 \mathrm{~mm}$ long at hatching with a preanal length of about $72 \%$ TL (from figure in Muus 1967). It possesses an adhesive organ 


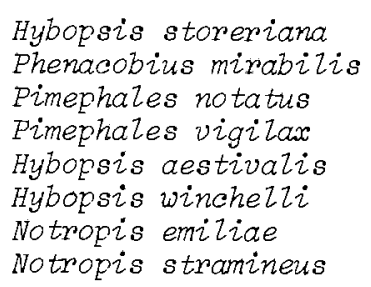

Hybopsis storeriana

Phenacobius mirabizis

Pimephales notatus

Pimephales vigizax

Hybopsis aestivalis

Hybopsis winchelzi

Notropis stramineus

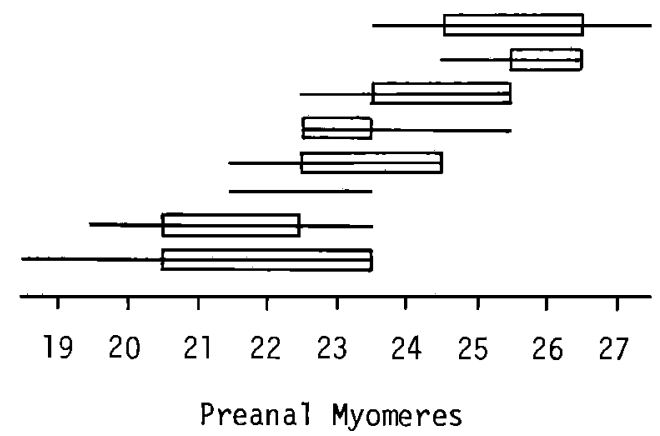

FIGURE 2.-Preanal myomere distributions for cyprinid larvae with a flattened eye. Lines are ranges; boxes enclose common values.

on the head by which it attaches to vegetation. Diagnostic pigmentation consists of a dark internal stripe that covers the dorsum of the yolk sac, continuing posteriad along the postanal venter. Other pigmentation is lacking. Larger larvae develop a conspicuous black patch on the end of the caudal peduncle. Pelvic buds develop at about $11 \mathrm{~mm}$. The 11 dorsal fin rays (three are spine-like) and single pair of barbels may be present in larvae. References: Kazansky (cited in Berg 1949), Kryzhanovsky (1947, 1949), Berg (1949), Bracken and Kennedy (1967), Muus (1967).

Rhodeus sericeus may belong to this group. Available illustrations show relative preanal lengths of 79,67 , and $64 \%$ at 5,6 , and $8 \mathrm{~mm}$, respectively. Small larvae (about $5-8 \mathrm{~mm}$ ) have a pair of horny lateral protruberances of the yolk sac that secures them among the gills of molluscs in which the eggs are deposited. Yolk is absorbed after $8 \mathrm{~mm}$. Larger larvae develop 12 to 13 dorsal fin rays (three are spine-like). Pelvic buds develop anterior to the dorsal fin origin. Larvae probably are collected rarely because they remain in the mantle cavity of a mollusc until about $20 \mathrm{~mm}$ (juveniles). References: Kryzhanovsky (1949), Kryzhanovsky et al. (1951), Nikolsky (1954), Muus (1967), Wheeler (1969).

\section{Eye Shape}

A few species have eyes with distinctly flattened dorsal and ventral borders (Fig. 1). This characteristic appears very early in many species but disappears rapidly. In some species it persists, is consistent within the species, and is not an artifact of preservation. In these instances, the eyes appear circular by the end of the larval period (this may be merely a result of further development of the overlying circumorbital bones). Myomere number is useful for separating some of these larvae (Fig. 2).

Phenacobius mirabilis is known only from 6.6 to $7.2 \mathrm{~mm}$. Dorsal melanophores are restricted to a few on the occiput. The venter shows the outlined-gut pattern described in a later section. The mouth is inferior and horizontal and the snout blunt and projecting. Internal melanophores develop immediately above the vertebral column. Yolk is absorbed by $8.0 \mathrm{~mm}$. Reference: Perry (1979).

Pimephales notatus has small larvae (for example, hatch, 5-6 mm; yolk absorption, about $6.0 \mathrm{~mm}$; pelvic-bud formation, $8-9 \mathrm{~mm}$ ). The venter shows the outlined-gut pattern. The mouth is subterminal to inferior once yolk is absorbed. Larger larvae develop a caudal spot and a concentration of melanophores at the dorsal fin base. References: Fish (1932), Buynak and Mohr (1979c), Loos et al. (1979), Perry and Menzel (1979), Heufelder and Fuiman (1982).

Pimephales vigilax is similar to $P$. notatus but somewhat smaller. There is an intermittent midventral row of melanophores (similar to that of Notropis atherinoides) after yolk absorption. A caudal spot and a concentration of melanophores develop at the dorsal-fin base and, on late larvae, a spot develops on the anterior part of the dorsal fin itself. The mouth is subterminal to inferior once yolk is absorbed (all comparative characters here are from JVC). References: Taber (1969), Conner et al. (1980), Heufelder and Fuiman (1982). 
Hybopsis aestivalis, $H$. storeriana, and at least older larvae of $H$. winchelli (JVC) exhibit a small, subterminal to nearly inferior mouth that is overhung by a fleshy snout at larger sizes. Pectoral buds or fins are long and expansive and usually placed ventrolaterally. Nares develop early and are rather large. Differentiation of Hybopsis species is difficult but myomere number is of some aid (Fig. 2). References: $H$. aestivalis-Bottrell et al. (1964), Conner et al. (1980); H. storeriana-Taber (1969), Conner et al. (1980).

Fish (1932) described larvae of Erinemus storerianus (=Hybopsis storeriana) but her identifications were doubted by Snyder and Douglas (1978) and Heufelder and Fuiman (1982). The presence of an oil globule, anterior placement of the anus, size of the mouth, and other characters indicate that all stages she described, except the juvenile, were those of a darter (Percidae). Her 21-mm juvenile is a cyprinid and may or may not be $H$. storeriana, but we cannot justify an alternative identification.

Taber (1969) illustrated a developmental series of Hybopsis storeriana and Heufelder and Fuiman (1982) reproduced these. At least the 6.5-, 7.6-, and 8.7-mm specimens were probably Pimephales vigilax, based on head shape and size at given stages of development when compared to data in Conner et al. (1980).

Hogue et al. (1976) depict their "group B, subgroups 1, 2, and 3" larvae and offer tentative identifications. We suggest that at least the photograph of group B, subgroup 1 represents Hybopsis storeriana and that of group B, subgroup 2 represents $H$. aestivalis. Hogue et al. tentatively identified their group B, subgroup 3 as $H$. insignis. Low total myomere counts reported by them $(34+)$ disagrees with that expected from vertebra counts (38 to 40 ).

Notropis emiliae is very similar to Pimephales vigilax, but it tends to have fewer preanal myomeres (Fig. 2). Further, it attains a ninth dorsal fin ray by the time pelvic buds appear, and no spot develops in the anterior part of the dorsal fin. Reference: Millard (1981).

Notropis stramineus from 4 to $7 \mathrm{~mm}$ may show scattered breast pigmentation, but smallest larvae may lack pigment entirely. Larger larvae sometimes develop the outlined-gut pattern. Late in the larval period, melanophores develop in the nasal pit and along the dorsal-fin base. Juveniles develop a dusky midlateral stripe.
References: Fish (1932), Loos and Fuiman (1978), Perry and Menzel (1979), Snyder (1981), Heufelder and Fuiman (1982).

Notropis cerasinus is poorly known. One illustration depicts a flattened eye. Reference: Loos and Fuiman (1978).

\section{Preanal Myomere Number}

Generally, myomere frequency distributions are symmetrical around a single (or double) heavily weighted mode (that is, they are positively kurtotic). Therefore, overlap at the extremes of two distributions usually represents a small proportion of either population. Preanal myomere number ranges approximately from 18 to 33 among cyprinids and a small group of genera have modal values greater than 25 ( $\mathrm{Ta}$ ble 1). Preanal myomere number is also a useful character for species within this group (Fig. 3). Many of these fishes also have the following characteristics in common: a broad, dark midlateral stripe, a caudal spot, and a less prominent ventrolateral stripe that crosses the length of the gut, descending to the heart anteriad (Fig. 1).

Ctenopharyngodon idella and Semotilus corporalis have the highest preanal myomere counts; the former was discussed in the previous section. Semotilus corporalis is larger than other cyprinids (hatch, $6.8-7.5 \mathrm{~mm}$; yolk absorption, about $10.6 \mathrm{~mm}$; pelvic-bud formation, 15.6 $\mathrm{mm})$. The caudal spot and midlateral stripe form by $15 \mathrm{~mm}$. The ventrolateral stripe tends to be well defined and complete (without gaps). Pelvic buds develop below the dorsal fin origin. References: Reed (1971), Jones et al. (1978), Buynak and Mohr (1979b), Loos et al. (1979), Heufelder and Fuiman (1982).

Semotilus atromaculatus is smaller than S. corporalis (hatch, 5.3-6.2 mm; yolk absorption, 8.9$9.3 \mathrm{~mm}$; pelvic-bud formation, $14-15 \mathrm{~mm}$ ), yet larger than most cyprinids. The midlateral stripe and confluent caudal spot form between 11 and $14 \mathrm{~mm}$. The ventrolateral stripe has gaps in the sequence of melanophores. The ventral edge of the operculum is marked with melanophores by about $9 \mathrm{~mm}$. Pelvic buds develop anterior to the dorsal fin origin. Predorsal length is $\mathbf{4 6}$ to $48 \%$ TL at 12 to $15 \mathrm{~mm}$. References: Fish (1932), Buynak and Mohr (1979b), Kranz et al. (1979), Loos et al. (1979), Perry and Menzel (1979).

Campostoma anomalum is very similar to $S$. 


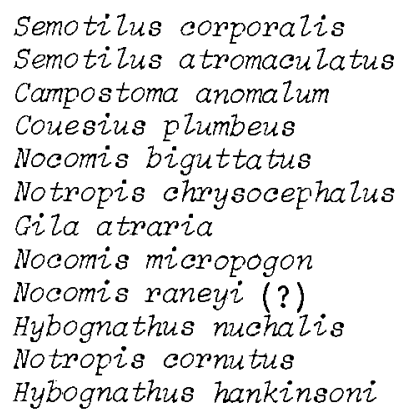

Semotilus corporalis

Semotilus atromaculatus

Campostoma anomalum

Conesius flumbeus

Nocomis biguttatus

Notropis chrysocephalus

Gi la atraria

Nocomis raneyi (?)

Hybognathus muchalis

Hybognathus hankinsoni

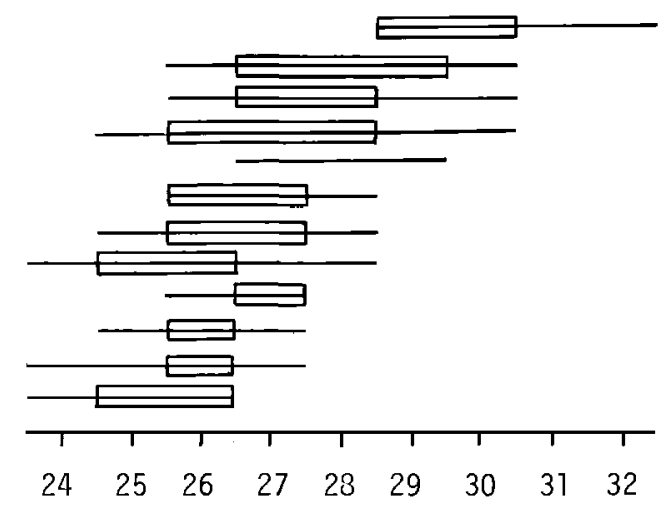

Preanal Myomeres

FIGURE 3.-Preanal myomere distributions for cyprinid larvae with many preanal myomeres. Lines are ranges; boxes enclose common values.

atromaculatus after caudal fin ray formation (until that time, the former is much darker [BFL]). Sizes at various stages are similar. The caudal spot of C. anomalum usually is separated from the midlateral stripe (forming at $9.3 \mathrm{~mm}$ ). Pelvic buds develop below the dorsal fin origin and the predorsal length is $43-45 \%$ TL at $12-13$ $\mathrm{mm}$. By $20 \mathrm{~mm}$, the diagnostic subterminal mouth and black peritoneum develop. References: Fish (1932), Reed (1958), Hogue et al. (1976), Loos et al. (1979), Perry and Menzel (1979), Buynak and Mohr (1980a), Heufelder and Fuiman (1982).

Couesius plumbeus is one of the smallest of this group, excepting Ctenopharyngodon idella (hatch, $5.8-6.4 \mathrm{~mm}$; yolk absorption, about $7.5 \mathrm{~mm}$; pelvic-bud formation, $11.3 \mathrm{~mm}$ ). The midlateral stripe is very narrow and the caudal spot is reduced. A second, smaller, hypaxial, caudal spot develops by $9.2-10.0 \mathrm{~mm}$. The ventrolateral stripe descends across the breast anteriorly, converging with its counterpart midventrally. Pelvic buds develop anterior to the dorsal fin origin. Unlike others of this group, Couesius plumbeus is usually lacustrine and enters the mouths of streams only to spawn. Reference: Fuiman and Baker (1981).

A trident-shaped pattern on the ventral foregut is described for Notropis chrysocephalus by Yeager (1979) but not illustrated. The outer tines of the trident ascend posteriad to become the ventrolateral stripes along the gut. Larvae are of moderate size (hatch, $5.6-6.0 \mathrm{~mm}$; yolk absorption, $7.8 \mathrm{~mm}$; pelvic-bud formation, 11.3-
$12.2 \mathrm{~mm}$ ). The caudal spot is absent. References: Loos and Fuiman (1978), Yeager (1979).

Fish (1932) described and illustrated Notropis cornutus chrysocephalus eggs and larvae. The specimens were incorrectly identified (Snyder et al. 1977; Loos and Fuiman 1978) and were probably a percid, perhaps Etheostoma sp.

Gila atraria is another small species in this group (hatch, about $4 \mathrm{~mm}$; yolk absorption, about $7 \mathrm{~mm}$; pelvic-bud formation, about 10 $\mathrm{mm}$ ). It is darkly pigmented with a short row of melanophores descending posteriad from the pectoral region. Melanophores also outline the caudal peduncle in lateral view. Reference: Snyder (1981).

Members of Nocomis belong to this group. Larvae of $N$. biguttatus and $N$. micropogon have been described and a 9.1-mm N. leptocephalus has been illustrated (Loos et al. 1979). A description of $N$. raneyi (Potter et al. 1980), based on a reared series from artificially fertilized eggs, is probably that of $N$. leptocephalus. Nocomis raneyi had not been identified from the stated locality for 15 years (R. E. Jenkins, personal communication with LAF) and the specimens from which gametes were taken were lost. All known Nocomis larvae were about the same size and similarly pigmented. The caudal spot of $N . b i$ guttatus is much larger and the caudal fin is reddish in living and freshly preserved material (LAF). References: $N$. biguttatus-Heufelder and Fuiman (1982); N. micropogon-Loos et al. (1979), Buynak and Mohr (1980a), Cooper (1980). 


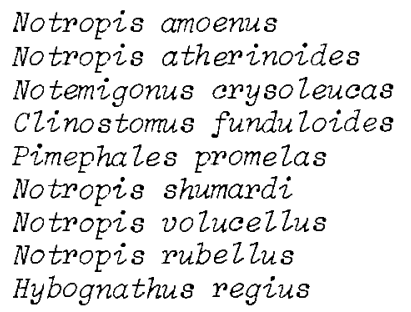

Notropis amoenus Notropis atherinoides Notemigonus crysoleucas Clinostomus funduloides Pimephales promelas Notropis shumardi Notropis volucellus Hybognathus regius

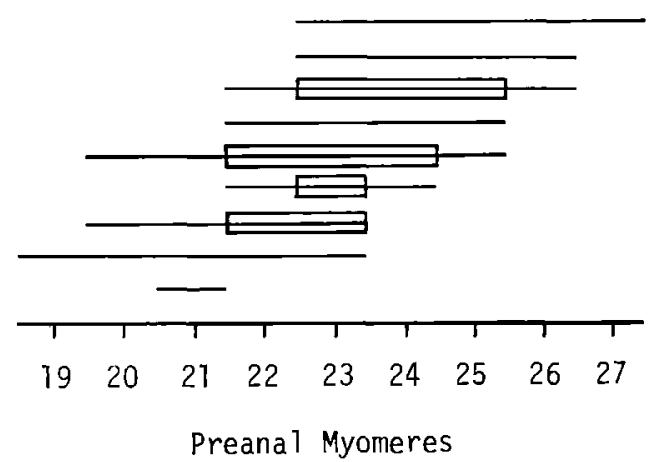

Figure 4.-Preanal myomere distributions for cyprinid larvae with a midventral stripe. Lines are ranges; boxes enclose common values.

Notropis cornutus is similar to Notropis chrysocephalus as larva and adult. Some populations do not exhibit the midventral stripe, which is usually present. Most specimens have a concentration of melanin at the tip of the urostyle. References: Loos and Fuiman (1978), Perry and Menzel (1979), Buynak and Mohr (1980a).

Hybognathus nuchalis is indistinguishable from others of its genus on the basis of qualitative characters. It is unique among southern Mississippi River cyprinids in that it has many preanal myomeres (24-27, usually 25 or 26 ) but few postanal myomeres (9-13, usually 11 or 12$)$ (JVC). Ecologically, these larvae (in Louisiana) are restricted to marginal areas of the inundated floodplain (where Ictiobus and Notemigonus larvae are abundant) and rarely are encountered in open-water collections (JVC).

Hybognathus hankinsoni does not develop ventrolateral stripes, but it does possess prominent melanophores on the pectoral fin base shortly after caudal fin-ray formation. There is a prominent midventral stripe anterior to the anus and the ventral edge of the operculum is lined with melanophores, as on Semotilus atromaculaius. Larger larvae lack a midlateral stripe and caudal spot. The pectoral and opercular pigmentation may not be present in other members of the genus. References: Perry and Menzel (1979), Snyder (1981), Heufelder and Fuiman (1982).

\section{Ventral Pigmentation}

A variety of melanophore patterns are found in cyprinids; the ventral pattern between the head and anus is helpful in grouping larvae
(Fig. 1). The pattern of melanophores, rather than their number, size, or intensity, appears to be a useful taxonomic character.

\section{Midventral Stripe}

Perhaps the most common arrangement of melanophores is in a median line between the head and anus. The stripe is usually developed by $4.6 \mathrm{~mm}$ and may vary in intensity due to the size or number of melanophores (Fig. 1). It is usually most linear along the base of the preanal fin fold. Anteriorly, it may be slightly more dispersed. Preanal myomere number is helpful to separate some species within this group (Fig. 4).

Notropis amoenus contains midventral pigment at hatching. Late larvae are similar to Notemigonus crysoleucas in that they develop pelvic buds anterior to the dorsal fin origin, have at least 11 anal fin rays, and have a pointed snout with a superior mouth. However, Notropis amoenus has fewer anal fin rays and is more slender than Notemigonus crysoleucas. References: Loos and Fuiman (1978), Buynak and Mohr (1980b).

Notropis atherinoides is more elongate than other cyprinids, superficially resembling clupeids. Pigment is sparse and the midventral stripe is intermittent, consisting of 5 to 10 melanophores. Pelvic buds develop anterior to the dorsal-fin origin and the anal fin develops at least 10 rays. References: Fish (1932), Flittner (1964), Hogue et al. (1976), Loos and Fuiman (1978), Conner et al. (1980).

Notemigonus crysoleucas is characterized by a concentration of melanophores around the tip of the urostyle (sometimes absent at hatching). 
Larvae are among the smallest cyprinids (hatch, $3.0 \mathrm{~mm}$; yolk absorption, $4.6 \mathrm{~mm}$; pelvic-bud formation, about $10.2 \mathrm{~mm}$ ). The mouth is always small and by $6 \mathrm{~mm}$ it is superior. Pelvic buds develop anterior to the dorsal-fin origin. The anal fin is falcate, usually with 12 to 13 rays when complete. Eggs are spawned among vegetation and newly hatched larvae attach to plants by means of an adhesive organ or gland on the top of the head. References: Lippson and Moran (1974), Hogue et al. (1976), Snyder et al. (1977), Loos et al. (1979), Wang and Kernehan (1979).

Fish (1932) described and illustrated an 18mm larva. The description appears to be that of Notemigonus crysoleucas, but the illustration differs on several points (Snyder et al. 1977). The placement of the pelvic fins, the shape of the anal fin, and the few anal-fin rays leads us to believe that the illustration is of Notropis cornutus or Notropis chrysocephalus.

Clinostomus funduloides may belong to this group. The best description available (Hogue et al. 1976) indicates the presence of a midventral stripe; however, an illustration in Loos et al. (1979) shows a scattering of melanophores between the heart and preanal fin fold. Hogue et al. (1976) described ventrolateral stripes (as in the high preanal myomere group) that cross the breast anteriorly to join midventrally near the heart, and pelvic buds anterior to the dorsal-fin origin. The mouth of older larvae is large and oblique. Dorsal-fin rays may be 8 or 9 . Pigmentary differences between the specimens in the two studies cited above may indicate great geographic variability in larvae of this species. At least three subspecies have been recognized and the specimens from these two studies were of different subspecies.

Pimephales promelas shows a midventral row of melanophores along, but usually not anterior to, the preanal fin fold. The mouth is terminal until the juvenile phase. Larger larvae develop a midlateral stripe and lack a caudal spot. In many respects, $P$. promelas resembles Notropis chrysocephalus and Notropis cornutus. References: Fish (1932), Hogue et al. (1976), Snyder et al. (1977), Buynak and Mohr (1979c), Perry and Menzel (1979).

Notropis shumardi is very similar to $N$. atherinoides, but in the lower Mississippi River, the former has an even weaker midventral stripe (3-7 melanophores), fewer preanal myomeres and anal-fin rays, and more posteriorly placed pelvic buds (JVC).

Notropis volucellus is most similar to, but is thinner, more delicate, and less pigmented throughout development than, Notropis amoenus (BFL). Midventral pigment is sometimes absent at hatching, but develops soon afterward. Pelvic buds develop below the dorsal-fin origin, the snout is blunt, and the anal fin contains $\mathbf{8}$ or 9 rays. References: Potter and Potter (1981), Heufelder and Fuiman (1982).

Notropis rubellus is darkly pigmented, with a sharply pointed snout. Pelvic buds develop anterior to the dorsal-fin origin and there are 9 to 11 anal-fin rays. Reference: Heufelder and Fuiman (1982).

A 15-mm Notropis rubrifrons ( $=N$. rubellus) illustrated by Fish (1932) is probably misidentified (Heufelder and Fuiman 1982), based on the position of the pelvic fins as illustrated.

Hybognathus regius larvae are known from descriptions under the name of $H$. nuchalis. However, the northern populations sampled in those descriptive studies subsequently were assigned to $H$. regius. Larvae are virtually indistinguishable from $H$. hankinsoni (see Preanal Myomere Number) except for having fewer preanal myomeres. References: Raney (1939), Mansueti and Hardy (1967), Lippson and Moran (1974), Jones et al. (1978), Wang and Kernehan (1979).

Notropis ardens is very similar to Notropis rubellus; it is darkly pigmented and has a pointed snout. Pelvic buds form posterior to the dorsalfin origin and 9 to 11 anal-fin rays develop. Reference: Loos and Fuiman (1978).

Notropis telescopus is not well known. Adults have 11 anal-fin rays which may be a useful character for older larvae. Reference: Loos and Fuiman (1978).

\section{Scattered Breast Melanophores}

When it occurs, a broad scatter of melanophores develops on the breast between the heart and the preanal fin fold (Fig. 1) by the time of yolk absorption. The pigment along the base of the preanal fin fold may be in the form of a stripe or entirely lacking.

Notropis hudsonius and $N$. dorsalis possess the broad scatter of melanophores from the breast to anus, which fades and eventually disappears by the juvenile period. One illustration of $N$. hudsonius (Loos and Fuiman 1978) depicts a flattened eye, which would place this species in 


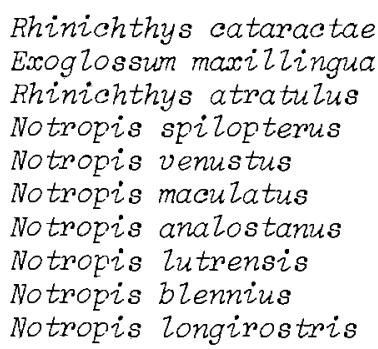

Phinichthys cataractae Exoglosswn maxizzingua Rhinichthys atratulus Notropis spizopterus Notropis venustus Notropis maculatus Notropis analostanus Notropis bzennius Notropis longirostris

FIGURE 5.-Preanal myomere distributions for cyprinid larvae with the outlined-gut pigment pattern. Lines are ranges; boxes enclose common values.

a different group according to our scheme; however, numerous other published figures do not support this illustration. Notropis hudsonius has 22-25 preanal myomeres, usually 23-25. Notropis dorsalis develops a prominent melanophore in the nasal pit by about $7 \mathrm{~mm}$ and has 20-22 preanal myomeres, usually 21 or 22 . References: $N$. hudsonius-Lippson and Moran (1974), Jones et al. (1978), Loos and Fuiman (1978), Loos et al. (1979), Wang and Kernehan (1979), Heufelder and Fuiman (1982); N. dorsalis-Loos and Fuiman (1978), Perry and Menzel (1979).

Loos and Fuiman (1978) and Snyder and Douglas (1978) stated that Fish's (1932) description and illustration of a $5.0-\mathrm{mm}$ Notropis hudsonius were incorrectly identified. This figure was reproduced by Mansueti and Hardy (1967). The body form and the presence of an oil globule suggest that the specimen may have been a percid. It is also possible that the 14.25 $\mathrm{mm}$ specimen (reproduced by Mansueti and Hardy 1967; Lippson and Moran 1974; Jones et al. 1978) was misidentified, based on the position and angle of the mouth as illustrated.

Notropis chalybaeus has a single dense stripe of melanophores on the dorsum, unlike the two parallel rows found in most other cyprinids. A dense caudal spot develops early (before 7.0 $\mathrm{mm}$ ). Larvae are small (hatch, $2.3 \mathrm{~mm}$; yolk absorption, about 3-4 mm; pelvic-bud formation, $9.2 \mathrm{~mm}$ ) with only 19 or 20 preanal myomeres. References: Marshall (1947), Jones et al. (1978), Loos and Fuiman (1978).

Notropis leuciodus and N. lutipinnis are poorly known. They hatch between 4.4 and $5.1 \mathrm{~mm}$. Pigment along the preanal fin fold is lacking. The anal fin ultimately contains 9 rays. Reference: Loos and Fuiman (1978).

Phoxinus oreas is also poorly known. It has several scattered melanophores on the venter of the breast. The pigment is less scattered than in the previous species of this group. Pigment along the preanal fin fold is lacking. Melanophores are aligned in diagonal rows along the myosepta. Reference: Loos et al. (1979).

\section{Outlined Gut}

Several species develop the ventrolateral stripe as described for the high-preanal-myomere group. When viewed from below, these stripes outline the visceral cavity (Fig. 1). Preanal myomere number may be of use within this group (Fig. 5).

Exoglossum maxillingua and two species of Rhinichthys are in this group. All are relatively larger than the other members (hatch, $5-6 \mathrm{~mm}$; yolk absorption, 7-9 mm; pelvic-bud formation, 11-14 mm), have uniformly scattered dorsal pigment by $7 \mathrm{~mm}$, and develop a frenum in late larval stages.

Exoglossum maxillingua tends to be more heavily pigmented than the Rhinichthys species. Prior to yolk absorption it develops a distinct caudal spot that nearly is separated from the midlateral stripe. The spot in both Rhinichthys species develops after yolk absorption as a widening of the midlateral stripe. Later, E. maxillingua develops pelvic buds below the dorsal-fin origin (Rhinichthys species develop them ante- 
riorly) and lacks maxillary barbels (Rhinichthys species develop small barbels). References: Fuiman and Loos (1978), Loos et al. (1979), Buynak and Mohr (1980a).

Rhinichthys atratulus and $R$. cataractae are very similar to one another. The former tends to have 25 preanal myomeres, the latter 26. Rhinichthys cataractae develops a subterminal to inferior mouth in the latter half of the larval period, whereas $R$. atratulus has a terminal mouth. A broad midlateral stripe develops by $9 \mathrm{~mm}$ in $R$. atratulus and the caudal spot extends into the caudal fin. In the congener, the broad stripe forms later (about $15 \mathrm{~mm}$ ) and the spot is almost confined to the peduncle. Dorsal pigmentation extends laterally to the midlateral stripe on $R$. cataractae, but does not reach the stripe on $R$. atratulus. References: $R$. atratulus-Fish (1932), Bartnik (1970), Fuiman and Loos (1977), Buynak and Mohr (1979a), Loos et al. (1979), Wang and Kernehan (1979); R. cataractae-Fish (1932), Bartnik (1970), Fuiman and Loos (1977), Buynak and Mohr (1979a), Loos et al. (1979), Cooper (1980).

Bartnik (1970) and Fuiman and Loos (1977) discussed characteristics of Rhinichthys atratulus meleagris, a subspecies occurring west of the Appalachian Mountains; other descriptions deal with the eastern form $R$. $a$. atratulus. Characteristics of these subspecies had little effect on the characters used for separating the species from $R$. cataractae. A comparison of the two subspecies showed a few pigmentary differences (Fuiman and Loos 1977). An illustration of a $13.7-\mathrm{mm} R$. cataractae (Fish 1932) has the characters of $R$. atratulus, as described by more recent studies, and, therefore, may be misidentified. Further, a preanal fin fold should have been present at that developmental stage, regardless of the species. It was probably inadvertently neglected by the artist.

Notropis spilopterus and N. analostanus are small (hatch, 4-5 mm; yolk absorption, about $6 \mathrm{~mm}$; pelvic-bud formation, about $9.3 \mathrm{~mm}$ ). The outlined gut develops early but may fade late in the larval period. Dorsal pigmentation is particularly sparse. A broad, but light, midlateral stripe without a caudal spot develops on juveniles. References: N. spilopterus-Hogue et al. (1976), Snyder et al. (1977), Loos and Fuiman (1978), Heufelder and Fuiman (1982); N. analostanus-Stone (1940), Mansueti and Hardy
(1967), Lippson and Moran (1974), Jones et al. (1978), Loos and Fuiman (1978).

Notropis lutrensis and $N$. venustus occasionally develop a short midventral row of melanophores in the heart region to complement the outlined gut pattern. Larvae are small (hatch, 4-5 mm; yolk absorption, about $5.0 \mathrm{~mm}$; pelvicbud formation, $8-9 \mathrm{~mm}$ ). Notropis venustus develops a caudal spot from the time pelvic buds appear. In the lower Mississippi River, N. venustus tends to have one or two more preanal myomeres than $N$. lutrensis (JVC). References: N. lutrensis-Saksena (1962), Taber (1969), Loos and Fuiman (1978), Perry and Menzel (1979), Snyder (1981); N. venustus-Taber (1969).

Notropis maculatus has the outlined-gut pattern but the ventrolateral lines are incomplete. The snout is attenuate and the large mouth is terminal. Late larvae develop a narrow midlateral stripe and a prominent caudal spot. Reference: Millard (1981).

Notropis procne develops an outlined-gut pattern after caudal fin-ray formation and is somewhat similar to $N$. hudsonius at this time. A few melanophores may develop midventrally anterior to the preanal fin fold. Internal melanophores form chevron-shaped patterns along the notochord that are not found in $N$. hudsonius. Only seven anal-fin rays develop. Reference: Loos and Fuiman (1978).

Although undescribed as larvae, Notropis blennius and $N$. longirostris are known in sufficient detail to assign them to this group. They ultimately develop seven anal-fin rays and larvae are qualitatively alike. Myomere counts differ (Fig. 5). They seldom are encountered together; the former is riverine and the latter prefers upland creeks (JVC). A single illustration of $N$. blennius is available (Conner et al. 1980).

\section{Unassigned Species}

Some details are known for larvae of a few species, but not enough to place them in the foregoing classification: Campostoma oligolepis (Heufelder and Fuiman 1982); Leuciscus idus (=Idus melanotus, Ryder 1887); Notropis bifrenatus (Harrington 1947); Notropis girardi (Moore 1944); Notropis leedsi and N. niveus (Loos and Fuiman 1978); and Scardinius erythrophthalmus (Kazansky, cited in Berg 1949; Bracken and Kennedy 1967; Wheeler 1969). 


\section{Discussion}

We caution again that these diagnoses are based on barely more than a third of the cyprinid species east of the Continental Divide. The larvae of some species among the 62 covered here remain poorly known. Our diagnostic criteria may falter as the remaining two-thirds of the species become known. However, the task of identification need not be based entirely upon morphological data. Distributions of many species discussed here, such as several of Notropis, do not overlap. Species with overlapping ranges may not be syntopic, thereby also eliminating comparisons. (This lack of syntopy may need to be demonstrated for larvae as well as adults.) Spawning season is an important clue to which larvae should be present at a given time and place. If two species have consecutive spawning seasons, the age of a larva (reflected by size, developmental stage, or otolith rings) is a useful character. Finally, adult characters, such as fin-ray number and fin position, can be applied to older larvae.

Morphological characters chosen here to separate groups of larvae were based upon their consistency and ease of application. Although these groups do not correspond to phyletic groups as defined by systematic schemes devised for the adults, all of the species grouped according to high relative preanal length are Eurasian introductions. Morphometric characters such as this have been of little value in larval-cyprinid taxonomy because of the difficulty in dealing with allometry in a practical fashion. Stable meristic characters are few in cyprinid larvae. Of these, myomere counts are taxonomically useful. The inclusion of caudal (postanal) myomeres may cause difficulties because their number may vary as a result of environmental factors or, in rare cases, posthatching development. However, total myomere number can be predicted from adults as total vertebra number (including four Weberian vertebrae) minus one (Fuiman 1982). Pigmentary characters can be valuable but one must recognize the great range of intensity to be found in these patterns. Wild-caught specimens are often pale, whereas laboratory-reared larvae are usually quite dark. Melanophore number in a certain area is seldom diagnostic as it is in some marine species. Gross patterns, such as preanal ventral pigmen- tation, appear to be consistent within species but may undergo ontogenetic changes, thereby rendering the patterns of transient importance. It is possible that dorsal pigmentation will be taxonomically useful. General larva size frequently is used in our diagnoses, based on size at three selected events (hatching, yolk absorption, and pelvic-bud formation). Many other events occur during development for which size is known and these data should be extracted from the literature for a more complete representation of general larval size. This type of character is often very useful but size has not been quantified for numerous stages of many species, and so detailed comparisons from the literature are difficult to make.

Descriptions of currently unknown larvae are needed for many purposes. Although larvae do not always form morphologically similar groups that correspond to established taxa (as demonstrated by Loos and Fuiman 1978), it is not unreasonable to expect some degree of diversity among genera. Larvae are unknown for three genera (Dionda, Ericymba, Hemitremia); they may be distinctive and thus important to a better understanding of the diversity of cyprinid larvae. A few species are quite common and have a widespread distribution (for example, Hybognathus placitus, Notropis buchanani, $N$. heterolepis, N. umbratilis, Phoxinus erythrogaster, Semotilus margarita), yet their larvae are unknown. Such common species should be described for more complete management of the communities in which they live. A few species (such as Gila nigrescens, Hybopsis cahni, Notropis callitaenia, and Phoxinus cumberlandensis) currently are endangered or threatened (Deacon et al. 1979). Descriptions of their larvae are necessary for proper analyses of reproductive success and early-life-history requirements; such analyses, in turn, are needed to support subsequent recovery of the species.

\section{References}

BARTNIK, V. G. 1970. Reproductive isolation between two sympatric dace, Rhinichthys atratulus and $R$. cataractae, in Manitoba. Journal of the Fisheries Research Board of Canada 27:2125-2141.

Battle, H. I. 1940. The embryology and larval development of the goldfish (Carassius auratus L.) from Lake Erie. Ohio Journal of Science 40:8293.

BERG, L. S. 1949. Freshwater fishes of the USSR 
and adjacent countries, volume 11, fourth edition. Translated from Russian: Israel Program for Scientific Translations, 1964, Jerusalem, Israel.

Bottrell, C. E., R. H. Ingersol, and R. W. Jones, 1964. Notes on the embryology, early development, and behavior of Hybopsis aestivalis tetranemus (Gilbert). Transactions of the American Microscopical Society 83:381-399.

Bracken, J. J., And M. P. Kennedy. 1967. A key to the identification of the eggs and young stages of coarse fish in Irish waters. Scientific Proceedings of the Royal Dublin Society Series B 2(12): 99-108.

BuYnak, G. L., ANd H. W. Mohr, Jr. 1979a. Larval development of the blacknose dace (Rhinichthys atratulus) and longnose dace (Rhinichthys cataractae) from a Susquehanna River tributary. Proceedings of the Pennsylvania Academy of Science $53: 56-60$.

Buynak, G. L., and H. W. Mohr, JR. 1979b. Larval development of creek chub and fallfish from two Susquehanna River tributaries. Progressive FishCulturist 41:124-129.

Buynak, G. L., AND H. W. Mohr, JR. 1979c. Larval development of the bluntnose minnow (Pimephales notatus) and fathead minnow (Pimephales promelas) from northeast Pennsylvania. Proceedings of the Pennsylvania Academy of Science 53: $172-176$.

Buynak, G. L., AND H. W. Mohr, JR. 1980a. Larval development of stoneroller, cutlips minnow, and river chub with diagnostic keys, including four additional cyprinids. Progressive Fish-Culturist 42:127-135.

BuYnak, G. L., AND H. W. MOHR, JR. 1980b. Larval development of golden shiner and comely shiner from northeastern Pennsylvania. Progressive FishCulturist 42:206-211.

Conner, J. V., R. P. Gallagher, and M. F. Chatry. 1980. Larval evidence for natural reproduction of the grass carp (Ctenopharyngodon idella) in the lower Mississippi River. United States Fish and Wildlife Service Biological Services Program FWS/ OBS-80/43:1-19.

Cooper, J. E. 1980. Egg, larval and juvenile development of longnose dace, Rhinichthys cataractae, and river chub, Nocomis micropogon, with notes on their hybridization. Copeia 1980:469-478.

Deacon, J. E., G. Kobetich, J. D. Williams, and S. Contreras. 1979. Fishes of North America endangered, threatened, or of special concern: 1979. Fisheries (Bethesda) 4(2):29-44.

FisH, M. P. 1932. Contributions to the early life histories of sixty-two species of fishes from Lake Erie and its tributary waters. United States $\mathrm{Bu}$ reau of Fisheries Bulletin 47:293-398.

Flittner, G. A. 1964. Morphometry and life history of the emerald shiner, Notropis atherinoides Rafinesque. Doctoral dissertation. University of Michigan, Ann Arbor, Michigan, USA.
Fu1man, L. A. 1982. Correspondence of myomeres and vertebrae and their natural variability during the first year of life in yellow perch. Pages 56-59 in C. F. Bryan, J. V. Conner, and F. M. Truesdale, editors. Proceedings of the fifth annual larval fish conference. Louisiana Cooperative Fishery Research Unit, Louisiana State University, Baton Rouge, Louisiana, USA.

Fuiman, L. A., And J. P. Baker. 1981. Larval stages of the Iake chub, Couesius plumbeus. Canadian Journal of Zoology 59:218-224.

Fuiman, L. A., AND J. J. Loos. 1977. Identifying characters of the early development of the daces Rhinichthys atratulus and $R$. cataractae (Osteichthyes:Cyprinidae). Proceedings of the Academy of Natural Sciences of Philadelphia 129(2):2332.

Fuiman, L. A., AND J. J. Loos. 1978. Morphological changes during the larval development of the cutlips minnow, Exoglossum maxillingua. Transactions of the American Fisheries Society 107: $605-612$.

Gerlach, J. M. 1983. Characters for distinguishing larvae of carp, Cyprinus carpio, and goldfish, Carassius auratus. Copeia 1983:116-121.

Harrington, R. W., JR. 1947. The early life history of the bridled shiner, Notropis bifrenatus (Cope). Copeia 1947:97-102.

Heufelder, G. R., And L. A. Fuiman. 1982. Family Cyprinidae, carps and minnows. Pages 174-344 in N. A. Auer, editor. Identification of larval fishes of the Great Lakes basin with emphasis on the Lake Michigan drainage. Great Lakes Fishery Commission, Special Publication 82-3, Ann Arbor, Michigan, USA.

Hogue, J. J., JR., R. Wallus, and L. K. Kay. 1976. Preliminary guide to the identification of larval fishes in the Tennessee River. Tennessee Valley Authority, Technical Note B19, Norris, Tennessee, USA.

Jones, P. W., F. D. Martin, and J. D. Hardy, JR. 1978. Development of fishes of the mid-Atlantic bight. An atlas of egg, larval and juvenile stages. Volume 1, Acipenseridae through Ictaluridae. United States Fish and Wildlife Service Biological Services Program FWS/OBS-78/12.

Kajishima, T. 1960. The normal developmental stages of the goldfish, Carassius auratus. Japanese Journal of Ichthyology 8:20-28.

Kranz, V. R., K. N. Mueller, and S. C. Douglas. 1979. Development of the young of the creek chub, Semotilus atromaculatus. Pages 100-119 in R. D. Hoyt, editor. Proceedings of the third symposium on larval fish. Western Kentucky University, Bowling Green, Kentucky, USA.

Kryzhanovsky, S. G. 1947. Systematics of the family of minnow fishes (Cyprinidae). Zoologicheskii Zhurnal 26:53-64.

Kryzhanovsky, S. G. 1949. Eco-morphological principles and patterns of development among minnows, loaches and catfishes. Part II, Ecolog- 
ical groups of fishes and patterns of their distribution. Academy of Sciences of the USSR. Trudy of the Institute of Animal Morphology 1949(1): 219-297. Translated from Russian: Fisheries Research Board of Canada, Translation Series 2945, 1974, Ottawa, Canada.

Kryzhanovsky, S. G., A. I. Smirnov, And S. G. SoIn. 1951. Materialy po razvitiiu ryb r. Amura. Trudy Amurskoi Ikhtiologicheskoi Ekspeditsii 19451949. Materialy k Poznaniyu Fauny i Flory SSSR Otdel Zoologicheskii 24:5-222. (In Russian.)

Lee, D. S., C. R. Gilbert, C. H. Hocutt, R. E. Jenkins, D. E. MCAllister, and J. R. Stauffer, JR. 1980. Atlas of North American freshwater fishes. North Carolina State Museum of Natural History, Raleigh, North Carolina, USA.

Lippson, A. J., AND R. L. Moran. 1974. Manual for identification of early developmental stages of fishes of the Potomac River estuary. Martin Marietta Corporation, Special Publication PPSP-MP13, Baltimore, Maryland, USA.

Loos, J. J., And L. A. Fumman. 1978. Subordinate taxa of the genus Notropis: a preliminary comparative survey of their developmental traits. Pages 1-50 in L. L. Olmstead, editor. Proceedings of the first symposium on freshwater larval fish. Duke Power Company, Huntersville, North Carolina, USA.

Loos, J. J., L. A. Fuiman, N. R. Foster, and E. K. JANkowski. 1979. Notes on early life histories of cyprinoid fishes of the upper Potomac River. Pages 93-139 in R. Wallus and C. W. Voigtlander, editors. Proceedings of a workshop on freshwater larval fishes. Tennessee Valley Authority, Norris, Tennessee, USA.

Mansueti, A. J., and J. D. Hardy, JR. 1967. Development of fishes of the Chesapeake Bay region, an atlas of egg, larval, and juvenile stages, part I. Natural Resources Institute, University of Maryland, Baltimore, Maryland, USA.

Marshall, N. 1947. Studies on the life history and ecology of Notropis chalybaeus (Cope). Journal of the Florida Academy of Science 9:163-188.

Millard, M. J. 1981. Comparative larval development of the pugnose minnow, Notropis emiliae, and the taillight shiner, Notropis maculatus (Pisces: Cyprinidae). Master's thesis. Louisiana State University, Baton Rouge, Louisiana, USA.

Moore, G. A. 1944. Notes on the early life history of Notropis girardi. Copeia 1944:209-214.

Muus, B. J. 1967. Freshwater fish of Britain and Europe. William Collins Sons, London, England.

Nakamura, M. N. 1969. Cyprinid fishes of Japanstudies on the life history of cyprinid fishes of Japan. Research Institute for Natural Resources, Special Publication 4, Tokyo, Japan.

Nikolsky, G. V. 1954. Special ichthyology, second edition. Translated from Russian: Israel Program for Scientific Translations, 1961, Jerusalem, Israel.

PERry, L. G. 1979. I. Identification of nine larval cyprinids inhabiting small northern rivers. II. Spatial and temporal patterns of larval fish drift in the upper Skunk River. Master's thesis. Iowa State University, Ames, Iowa, USA.

Perry, L. G., ANd B. W. Menzel. 1979. Identification of nine larval cyprinids inhabiting small northern rivers. Pages 141-173 in R. Wallus and C. W. Voigtlander, editors. Proceedings of a workshop on freshwater larval fishes. Tennessee Valley Authority, Norris, Tennessee, USA.

Potter, W. A., J. J. Loos, And J. M. Potter. 1980. Development of larval bull chub, Nocomis raneyi. United States Fish and Wildlife Service Biological Services Program FWS/OBS-80/43:20-24.

Potter, W. A., ANd J. M. Potter. 1981. Description of protolarva mimic shiner (Notropis volucellus). Ohio Journal of Science 81:135-137.

Raney, E. C. 1939. The breeding habits of the silvery minnow, Hybognathus regius Girard. American Midland Naturalist 21:674-680.

ReED, R. J. 1958. The early life history of two cyprinids, Notropis rubellus and Campostoma anomalum pullum. Copeia 1958:325-327.

REED, R. J. 1971. Biology of the fallfish, Semotilus corporalis (Pisces, Cyprinidae). Transactions of the American Fisheries Society 100:717-725.

Robins, C. R., AND Six COAUThors. 1980. A list of common and scientific names of fishes from the United States and Canada, fourth edition. American Fisheries Society Special Publication 12.

RydeR, J. A. 1887. On the development of osseous fishes, including narine and freshwater forms. United States Commissioner of Fish and Fisheries Report (1885) 13:489-604.

Saksena, V. P. 1962. The posthatching stages of the red shiner, Notropis lutrensis. Copeia 1962:539544.

Smallwood, W. M., and M. L. Smallwood, 1931. The development of the carp, Cyprinus carpio, with special reference to the development of the intestinal tract. Journal of Morphology 51:217-231.

SNYDER, D. E. 1981. Contributions to a guide to the cypriniform fish larvae of the upper Colorado River system in Colorado. United States Bureau of Land Management, Biological Sciences Series 3, Denver, Colorado, USA.

SNyder, D. E., AND S. C. Douglas. 1978. Description and identification of mooneye, Hiodon tergisus, protolarvae. Transactions of the American Fisheries Society 107:590-594.

Snyder, D. E., M. B. M. SNyder, and S. C. Douglas. I977. Identification of golden shiner, Notemigonus crysoleucas, spotfin shiner, Notropis spilopterus, and fathead minnow, Pimephales promelas, larvae. Journal of the Fisheries Research Board of Canada 34:1397-1409.

Soin, S. G., And A. I. Sukhanova. 1972. Comparative morphological analysis of the development of the grass carp, the black carp, the silver carp, and the bighead (Cyprinidae). Journal of Ichthyology 12:61-71. 
Stone, U. B. 1940. Studies on the biology of the satinfin minnows, Notropis analostanus and Notropis spilopterus. Doctoral dissertation. Cornell University, Ithaca, New York, USA.

Taber, C. A. 1969. The distribution and identification of larval fishes in the Buncombe Creek arm of Lake Texoma with observations on spawning habits and relative abundance. Doctoral dissertation. University of Oklahoma, Norman, Oklahoma, USA.

WANG, J. C. S., AND R. J. Kernehan. 1979. Fishes of the Delaware estuaries: a guide to the early life histories. EA Communications, division of Ecological Analysts, Towson, Maryland, USA.

Wheeler, A. 1969. The fishes of the British Isles and north-west Europe. MacMillan, London, England.

YEAGER, B. 1979. Larval and early juvenile development of the striped shiner, Notropis chrysocephalus (Rafinesque). Pages 61-9l in R. Wallus and C. W. Voigtlander, editors. Proceedings of a workshop on freshwater larval fishes. Tennessee Valley Authority, Norris, Tennessee, USA. 